\title{
The Poverty under the light of the Neurosciences
}

Keywords: poverty, neurosciences, neurophilosophy, society, mental health, education, voluntary poverty

\section{Introduction}

As the economic crisis continues all over the world ${ }^{1}$ and the distance between financial inequalities, the 'rich-poor gap', that varies considerably across countries, increases constantly, the dimensions of the problem of situational poverty are also augmented in the increasingly globalizing society of our Era. ${ }^{2}$

Although the alleviation of the financial crisis remains a core issue in the social and humanitarian policy of all countries, the poverty is consistently ascending, affecting the psychosocial homeostasis of millions of people, exerting serious long-term effects on personal and social wellbeing, given that it is a main contributor to many serious social and legal problems.

In most countries, which are members of the European Union (EU) the definition of poverty sets as critical poverty threshold the 50 or 60 per cent of median national income..$^{3-6}$ Consequently, although the stages of the poverty for persons or families are related to the financial status of the society or the country in which they live, however the poverty is mostly conceptualized on the basis of the minimum acceptable living standard, which is approved by society. ${ }^{7}$

In some of the critical stages of the human life, such as in childhood, the poverty is mostly associated with serious physical, psychological, emotional and educational problems, ${ }^{8}$ which may exercise a somber influence upon the quality of their life. ${ }^{9}$ In the advanced age also, in senility particularly, the burden of poverty is critical for the character of life's epilogue.

It is expectable that poverty induces a long chain of stressful conditions upon the suffering communities or persons, with serious physiological effects on children and elderly people, affecting the personal emotional stability and the harmony of interpersonal communication in the family and the work environments, with long-lasting consequences on the physical, mental and social health, embarrassing the social-emotional development of the persons. ${ }^{10-13}$ Thus the poverty was associated in a high proportion of societies with powerlessness, unstable manual labor, psychological or mental instability, low educational levels and social and legal problems.

\section{Poverty and mental health}

There are multiple potential links between low economic incomes, deprivation and health status. Poverty and unemployment may be considered as potential risk factors for mental disorders according to WHO, ${ }^{14}$ since higher incidence of mental morbidity, associated with mortality and physical or intellectual disability has been reporter in low income communities than in prosperous ones. ${ }^{15-19}$

It has been reported that the nonpsychotic psychiatric morbidity, that is mostly constituted by the feeling of anxiety, frustration, depression, social insecurity and psychosomatic phenomena are mainly prevalent among people who live under the condition of poverty and material deprivation ${ }^{20,21}$ and face serious humanitarian problems and emotional distress. ${ }^{22,23}$ In addition, the persistent generational poverty in association with the psychological or mental distress affects the capacity of the person to re-integrate into society by building supportive social relationships or by participating in productive activities, ${ }^{24}$ a phenomenon that is mostly common in communities of low-income countries, where mental illness and poverty interact in a vicious circle.

From the psychological point of view, long lasting poverty induces, as a rule, the sense of insecurity, helplessness and humiliation, increasing therefor the despair and the further social isolation of the individual, ${ }^{25}$ given that each additional year in poverty increases the deprivation and makes the possibility of recovery obscure and scarcely achievable.

\section{Effects on woman's mental health}

Although poverty has negative mental health consequences for both men and women, greater mental phenomena are observed in women than in men. Women who live under serious financially strained circumstances, particularly single parent women and widows having all the economic and social responsibilities of the family face chronic stressful experiences continuously, which are mostly associated with inadequate incomes, neighborhood insecurity, without any substantial support from friends, relatives, church or society. Under those unhappy circumstances they may suffer from anxiety and depression more frequently than other women. ${ }^{26,27}$

\section{Effects on child's mental health}

The consequences of poverty ${ }^{28}$ and parental mental health seems to affect the children and adolescents considerably, since depression, anxiety, low cognitive performance, attention deficit/hyperactivity disorder, panic reactions, eating disorders such as anorexia nervosa, personality disorders, anti-social, aggressive and impulsive behaviour, increased risk of tabaco, cannabis, ${ }^{29}$ drug and alcohol use, school dropout and negative peer group affiliations, as well as involvement with the legal system are more pronounced in children and adolescents of poor or low income families, with mentally ill parents, than in children who live under better socioeconomic conditions in a healthy parental environment. 


\section{Effects on adolescent's mental health}

In addition, adolescence, which is a crucial stage of major life transition, characterized by obvious sensitivity in social adjustment, creates vulnerability in noxious environmental and social factors, that is mostly accentuated by poverty, frequently resulting in serious and persistent psychological youth problems, that may further affect their homeostatic equilibriums in adulthood. ${ }^{30}$

Reasonably, parental suicide, depression, posttraumatic stress disorder (PTSD), alcoholism, ${ }^{31}$ violence, ${ }^{32}$ insufficient interactions with their children or ineffective parenting, poor cognitive stimulation, marriage instability, which are frequently associated with unemployment, leading to absolute poverty or serious material deprivation, all of them are tragic phenomena that have catastrophic consequences on children's mental health. ${ }^{33}$

As a matter of fact, the poverty frequently affects both physical and mental health of the children, since the low socioeconomic status has serious consequences upon the parental health care, the housing quality, the marital stability, the nutrition adequacy of the children, the medical care and the pediatric following $u^{34}$ and overall the children live, as a rule under a stressful psychological atmosphere and have marked deficiencies in learning. It was observed that maternal physical illness has slighter gravity for children's mental health than the maternal mental health disorders. ${ }^{35}$

\section{Phenomena in immigrants}

It is important that in cases of immigration, although immigrant families live usually in poorer conditions than the host country counterparts $^{36}$ or sometimes in deep poverty, the children, the girls particularly, are not mentally affected. In the large majority of families who adapt successfully to their new environments, the children perform sufficiently at school, outperforming their indigenous classmates frequently. ${ }^{37,38}$ Nevertheless in some immigrant families who stay poor for long, socializing mostly with their poor native counterparts, the children remain helpless, isolated, having less exposure to the world due to lack of knowledge, language fluency and adequate vocabulary. Most of them have low self-esteem, feel powerless, unsafe, living under lasting condition of psychologically withdrawal, ${ }^{37}$ violence, fear, distrust and social disengagement. ${ }^{39}$

It is important that efforts to alleviate poverty promptly protect families from negative socio-economic consequences affecting the social behavior of the children. ${ }^{40}$ The amelioration of the financial and social status of the family would exercise a positive effect on the mental and psychological health of the family ${ }^{41}$ and would be a crucial component of children's emotional stability and mental health. ${ }^{42-44}$

A prompt escape from the labyrinth of the poverty have been linked to marked declines in children psychological problems. ${ }^{45}$ Otherwise, persisting mental health problems in childhood would become longstanding and difficult to be treated in adulthood.

In case of massive immigration, the application of beneficial programs in order to alleviating immigrant family's poverty, ameliorating the conditions of life, creating job training programs and providing job access to parents, would greatly increase the perspectives of children's mental health, as well as their dignity and social prosperity ${ }^{46,47}$ Pastoral care may also contribute greatly in providing counseling, psychological and spiritual support and proper education ${ }^{48}$ and even housing to homeless population.

\section{Poverty and brain development}

It is important that poverty may have a negative impact on brain development, affecting probably the organization and the plasticity of neuronal networks ${ }^{49,50}$ in areas of the brain associated with working memory, attentional processes, inhibitory control, emotion and behavior, such as hippocampus, amygdala, temporal, frontal cortex and cerebellum. ${ }^{51-53}$

Developmental cognitive neuroscience research has found that both gray and white matter are vulnerable to environmental disharmonic conditions. ${ }^{54}$ Even early studies in the field of neuroscience attempted to clarify whether the effects of exposure to deprived environments, might modify the morphological harmony of the brain's cytoarchitecture in experimental animals. ${ }^{55}$

Clinical studies revealed that children who were grown under conditions of nutritional deprivation and psychological distress showed smaller hippocampus and amygdala in neuroimaging, in comparison with children who lived under sufficient nutritional and psychological conditions. ${ }^{56,57}$ The advances in neuroimaging later on enabled the analysis of neural networks in studies focused on the influence of poverty on brain development. ${ }^{58}$ A substantial body of evidence from those studies suggested that poverty has a negative effect on the gray matter of the hippocampus and the frontal lobe at early childhood, ${ }^{59}$ resulting in memory impairment and emotional instability, affecting the learning capacity and the social performance of the children and deteriorating their quality of life evidently. ${ }^{60}$

The frontal lobe also, which is an area of executive functions, planning, attention, self-control, emotional and impulse control as well as harmonious social performance would be particularly vulnerable to noxious effects of stressful experience in childhood, affecting its development, as well as the neuronal plasticity, the dendritic arborization and the synaptogenesis. Persistent poverty in childhood affects also the organization of specific functional areas of the cortex of the temporal and parietal lobes, the cerebellar cortex and the cytoarchitecture of subcortical structures. ${ }^{61,62}$ Consequently morphological or functional alterations in the frontal lobe may be related with learning difficulties, decrements in attentional processes and behavioral problems seen in children from families who live in poverty. ${ }^{63,64}$

These findings from the clinical and experimental research in the field of neurosciences, emphasize the importance of the professional caregiving and sufficient education to children of poor families that should be a specific target for the welfare programs of the society. In general, a core concern of the welfare by church or the society must be the prompt offer of efficient assistance and support to any impoverished family or citizen.

\section{Voluntary poverty}

Voluntary poverty is the bright face of poverty, which is too different from the generational, situational or relative type of poverty. From the Greek antiquity philosophers emphasized the value of the spiritual wealth and considered the material poverty as a way to purity and spiritual perfectionism. According to Heracletus, one of the greatest Ionian philosophers who lived in solitude and poverty, "a prosperous society can only be conceived as one in which people have the capability and the strength to live in noble simplicity, in honesty, in purity, in light, overpassing the economic crisis by the strength of the mind". ${ }^{65}$ 
The prosperity of the society is mainly based on spiritual values, the wisdom, the truth, the illumination of the mind, the brightness of the soul, the capacity to self-knowing and sound thinking, the honesty, the purity, the prudence and the unapparent harmony of the interior life. ${ }^{66}$ All people ought to know themselves, being even-minded, since all humans have the capacity to self-knowing and sound thinking. Wisdom is the oneness of mind that guides and permeates all things.

The Stoics ${ }^{67}$ and Neoplatonics, ${ }^{68}$ believed also that the man should live in poverty and simplicity focusing their activity almost exclusively on meditation, mental purity and spiritual perfection. Plotinus, who himself use to live in poverty, proclaimed the eventual victory of the spirit over the flesh. The human being is a spiritual entity employing a body, as an active instrument of its temporal terrestrial life. A person can behave by acting solely intellectually and the soul must be continuously elevated towards the absolute Goodness, escaping from the tragic narrow cage of the perishable body. ${ }^{69}$

According to Anaxagoras the human being has to live in simplicity, poverty, self-concentration, self-control endeavoring to understand deeply the power of the Mind (Noṽs), who is unique, original, eternal, authentic, autonomous, unlimited unmixed with anything else, remaining pure and alone itself by itself, self-powered, self-subsistent, self-sufficient, separated completely from all other elements. ${ }^{70}$

In the range of the existential philosophy, according to Kierkegaard, the human being is an existing infinite Spirit ${ }^{71}$ and Mind. Thinking and understanding, may have either an aesthetic-intellectual character or an ethico-religious one, depending on the intelligence, wisdom, spiritual culture and mind's elevation of the human being. ${ }^{72}$

For centuries many philosophers decided to live in poverty and solitude endeavoring to contemplate the serenity and the inner harmony ${ }^{73}$ fighting against the passions of the soul, ${ }^{74,75}$ searching for the existential authenticity and the real way to the truth, ${ }^{76,77}$ beyond the turbulence of the society, the contradictions, the hard competitions, the hostility, the materialistic eudemonism, the economic discrepancies, ${ }^{78}$ the politics and the social dispute under various political theories and dominant tendencies. ${ }^{79}$

In the practice of religious life, the concept of purification and spiritual elevation by living in solitude without any possession has dignified voluntary poverty as a way of sanctification. Thus many persons ${ }^{80}$ for centuries gave up all their possessions in order to pass an ascetic way of life in continuous prayer and deep repentance ${ }^{81}$ living in voluntary poverty inside cells, sketes and monasteries.

In those ascetic establishments, which were founded in many parts of the world men and women devoted their time to praying and worshiping unceasingly, leading a high spiritual life and offering excellent writings, ${ }^{82}$ proofs of inner peace and harmony, faith, contemplation, serenity, purity of the heart and sanctity, which are precious documents of religious psychology and philosophy of a substantial psychotherapeutic validity. ${ }^{83,84}$

\section{Acknowledgments}

None.

\section{Conflicts of interest}

The authors declare no conflicts of interest.

\section{References}

1. Elsby MW, Hobijn B, Sahin A. The labor market in the great recession. NBER Working Paper No.15979.

2. Nolan B, Christopher TW. Resources, deprivation, and poverty. OUP Catalogue. 1996.

3. European Commission. Poverty and Exclusion, Special Eurobarometer 279 / Wave 67.1, Brussels, 2007. p 200.

4. European Commission. Commission Staff Working Document. Joint Report on Social Protection and Social Inclusion, Brussels, 2009. p. 190.

5. Goedemé T, Rottiers S. Poverty in the enlarged European Union. A discussion about definitions and reference groups. Sociology Compass. 2011;5(1):77-91.

6. Sen A. A Sociological Approach to the Measurement of Poverty: A Reply to Professor Peter Townsend. Oxford Economic Papers. 1985;37(4):669-676.

7. Townsend P. Poverty in the United Kingdom. A Survey of Household Resources and Standards of Living. Middlesex: Penguin Books; 1979. p. 1216.

8. Bailey MJ, Dynarski SM. Inequality in postsecondary education. In: G Duncan, R Murnane, editors. Whither opportunity: Rising inequality, schools, and children's life chances. NY: Russell Sage Foundation. 2011. pp. 117-132.

9. Duncan G J, Brooks-Gunn J. The consequences of growing up poor. NY: Russell Sage Foundation. 1997.

10. Shonkoff J, Gardner AS. The lifelong effects of early childhood adversity and toxic stress. Pediatrics. 2012;129(1):232-246.

11. Shaw DS, Dishion TJ, Supplee LH, et al. A family-centered approach to the prevention of early-onset antisocial behavior: Two-year effects of the family checkup in early childhood. Journal of Consulting and Clinical Psychology. 2012;206;74.

12. Moore R. Definitions of fuel poverty: Implications for policy. Energy Policy. 2012;49:19-26.

13. Aber L, Morris P, Raver C. Children, Families and Poverty: Definitions, Trends, Emerging Science and Implications for Policy. Social Policy Report. 2012;26(3).

14. World Health Organization (WHO). Investing in mental health. 2003.

15. Regire DA, Farmer ME, Rae DS, et al. One-month prevalence of mental disorders in the United States and sociodemographic characteristics: the Epidemiologic Catchment Area study. Acta Psychiatr Scand. $1993 ; 88: 35-47$.

16. Weich S, Lewis G. Poverty, unemployment, and common mental disorders: population based cohort study. BMJ. 1998;317(7151):115119

17. Burns JK. Poverty, inequality and a political economy of mental health. Epidemiology and psychiatric sciences. 2015;24(2):107-113.

18. Lozano R, Naghavi M, Foreman K, et al. Global and regional mortality from 235 causes of death for 20 age groups in 1990 and 2010: a systematic analysis for the Global Burden of Disease Study. Lancet. 2012;380(9859):2095-2128.

19. Hill TD, Ross CE, Angel RJ. Neighborhood disorder, psychophysiological distress, and health. J Health Soc Behav. 2005;46(2):170-186.

20. Mills C. The psychiatrization of poverty: Rethinking the mental health-poverty nexus. Social and Personality Psychology Compass 2015;9(5):213-222. 
21. Lund C. Poverty and mental health: towards a research agenda for low and middle-income countries. Commentary on Tampubolon and Hanandita. Soc Sci Med. 2014;111:134-136.

22. Reijneveld SA, Schene AH. Higher prevalence of mental disorders in socioeconomically deprived urban areas in the Netherlands: community or personal disadvantage? J Epidemiol Community Health. 1998;52(1):2-7.

23. Patel V, Gwanzura F, Simunyu E, et al. The explanatory models and phenomenology of common mental disorder in Harare, Zimbabwe. Psychol Med. 1995;25(6):1191-1199.

24. Robert DW. Poverty and mental health: A qualitative study of residentia care facility tenants. Community Ment Health J. 2003;39(1):139-156.

25. Kuruvilla A, Jacob KS. Poverty, social stress \& mental health. Indian J Med Res. 2007;126(4):273.

26. Kaplan G, Roberts R, Camaeho $\mathrm{T}$, et al. Psychosocial predictor of depression: Prospective evidence from the Human Population Laboratory Studies. Am J Epidemiol. 1987;125(2):206-220.

27. Belle D. Poverty and women's mental health. American psychologist. 1990;45(3):385.

28. DeSA UN. World population prospects: the 2012 revision. Population division of the department of economic and social affairs of the United Nations Secretariat, New York, 18. 2013.

29. Degenhardt L, Ferrari AJ, Calabria B, et al. The global epidemiology and contribution of cannabis use and dependence to the global burden of disease: results from the GBD 2010 study. PLOS ONE. 2013;8(10):7663.

30. Dashiff C, DiMicco W, Myers B, et al. Poverty and adolescent mental health. J Child Adolesc Psychiatr Nurs. 2009;22(1):23-32.

31. Nemtsov AV. Estimates of total alcohol consumption in Russia, 1980 1994. Drug and Alcohol Depend. 2000;58(1-2):133-142.

32. Veltischev DY. Violence and Health of the Population of Russia Moscow Scientific-Research Institute of Psychiatry of the Ministry of Health of the Russian Federation, WHO, Geneva. 2003.

33. Whitley E, Gunnell D, Dorling D, et al. Ecological study of socia fragmentation, poverty, and suicide. BMJ. 1999;319(7216):1034-1037.

34. Berger LM, Paxson C, Waldfogel J. Income and child Development Child and Youth Serv Rev. 2009;31(9):978-989.

35. National Council of Welfare. Poverty Profile 1996.Ottawa: Minister of Public Works and Government Services Canada; 1998. Catalogue H67-1/4-1996E

36. Munroe-Blum H, Boyle MG, Offord DR, et al. Immigrant children: psychiatric disorder, school performance, and service utilization. Am J Orthopsychiatry. 1989;59(4):510-519.

37. Beiser M, Hou F, Hyman I, et al. Poverty, family process, and the mental health of immigrant children in Canada. Am J Public Health. 2002;92(2):220-227.

38. Fitzsimons E, Goodman A, Kelly E, et al. Poverty dynamics and parenta mental health: Determinants of childhood mental health in the UK. Soc Sci Med. 2017;175:43-51.

39. Marans S, Adnopoz J, Berkman M, et al. The police mental health partnership: A community-based response to urban violence. New Haven, CT: Yale University Press. 1995.

40. McLeod J D, Shanahan MJ. Trajectories of poverty and children's mental health. J Health Soc Behav. 1996;37(3):207-220.

41. Fernald LCH, Gertler PJ, Neufeld LM. Role of cash in conditional cash transfer programmes for child health, growth, anddevelopment: an analysis of Mexico's Oportunidades. Lancet. 2008;371:828-237.
42. Strohschein L. Household income histories and child mental health trajectories. J Health Soc Behav. 2005;46(4):359-375.

43. National Institute of Child Health and Human Development Early Child Care Research Network. Duration and developmental timing of poverty and children's cognitive and social development from birth through third grade. Child Dev. 2005;76(4):795-810.

44. Ezpeleta L, Keeler G, Erkanli A, et al. Epidemiology of psychiatric disability in childhood and adolescence. Journal of Child Psychology and Psychiatry and Allied Disciplines. 2001;42(7):901-914.

45. Costello EJ, Compton SN, Keeler G, et al. Relationships between poverty and psychopathology: A natural experiment. JAMA. 2003;290(15):2023-2039.

46. Perkins CA. Age patterns of victims of serious violent crime. Washington, DC: US Dept of Justice. 1997.

47. Santiago CD, Kaltman S, Miranda J. Poverty and mental health: how do low $\square$ income adults and children fare in psychotherapy?. J Clin Psychol. 2013;69(2):115-126.

48. Young J L, Griffith EE, Williams DR. The integral role of pastoral counseling by African-American clergy in community mental health Psychiatr Serv. 2003;54(5):688-692.

49. Anderson BJ. Plasticity of gray matter volume: The cellular and synaptic plasticity that underlies volumetric change. Dev Psychobiol. 2011;53(5):456-465

50. Mohammed AH, Zhu SW, Darmopil S, et al. Environmental enrichment and the brain. Prog Brain Res. 2002;138:109-133.

51. Mezzacappa E. Alerting, orienting, and executive attention: Developmental properties and socio-demographic correlates in an epidemiological sample of young, urban children. Child Dev. 2004;75(5):1373-1138.

52. Evans GW, Schamberg MA. Childhood poverty, chronic stress, and adult working memory. Proc Natl Acad Sci USA. 2009;106(16):6545-6549.

53. van Praag $H$, Kempermann G, Gage FH. Neural consequences of environmental enrichment. Nat Rev Neurosci. 2000;1(3):191-198.

54. Lupien SJ, McEwen BS, Gunnar MR, et al. Effects of stress throughout the lifespan on the brain, behaviour and cognition. Nat Rev Neurosci. 2009;10(6):434-445.

55. Hebb D. The Organization of Behavior. New York: John Wiley \& Sons; 1949.

56. Noble KG, Houston SM, Kan E, et al. Neural correlates of socioeconomic status in the developing human brain. Dev Sci. 2012;15(4):516-527.

57. Jednoróg K, Altarelli I, Monzalvo K, et al. The influence of socioeconomic status on children's brain structure. PLoS One. 2012;7(8):e42486.

58. Kishiyama MM, Boyce WT, Jimenez AM, et al. Socioeconomic disparities affect prefrontal function in children. $J$ Cogn Neurosci. 2009;21(6):1106-1115.

59. Gao W, Zhu H, Giovanello KS, et al. Evidence on the emergence of the brain's default network from 2 week-old to 2-year old healthy pediatric subjects. Proc Natl Acad Sci USA. 2009;106(16):6790-6795.

60. Toga AW, Thompson PM, Sowell ER. Mapping brain maturation. Trends Neurosci. 2006;29(3):148-159.

61. Johnson SB, Riis JL, Noble KG. State of the art review: poverty and the developing brain. Pediatrics. 2016;137(4):e20153075.

62. Kleim JA, Jones TA, Schallert T. Motor enrichment and the induction of plasticity before or after brain injury. Neurochem Res. 2003;28(11):17571769. 
63. Luby J, Belden A, Botteron K, et al. The effects of poverty on childhood brain development: the mediating effect of caregiving and stressful life events. JAMA pediatrics. 2013;167(12):1135-1142.

64. Hanson JL, Hair N, Shen DG, et al. Correction: Family Poverty Affects the Rate of Human Infant Brain Growth. PLOS ONE. 2015;10(12): 0146434

65. Baloyannis SJ. The philosophy of Heracletus today. Encephalos. 2013;50:1-21,

66. Diels H, Kranz W. Die Fragmente der Vorsokratiker,Berlin: Weidmannsche Verlags- buchhandlung,1951.

67. Epicteti Dissertationes ab Arriani digestae H.Schenkl,Stutgardiae aed. Teubneri 1965 .

68. Plotinus. In 7 volumes, Greek text with English translation by $\mathrm{AH}$ Armstrong. MA Loeb Classical Library, Cambridge, UK. 1968.

69. Davarinou PG. Plotinus' attempts to go beyond the Platonic philosophy. Thesis, Athens, Greece. 1995.

70. Baloyannis SJ. Anaxagoras on Mind. J Neurol Stroke. 2018;8(1):00269.

71. Kierkegaard S. Kierkegaard's Writings, Vii: Philosophical Fragments, or a Fragment of Philosophy/Johannes Climacus, or de Omnibus Dubitandum Est Princeton University Press. 1985.

72. Baloyannis SJ. Kierkegaard's melancholy in his life and philosophy. Gregorius Palamas. 1988;81:303-351.

73. Baloyannis SJ. The philosophy of solitude. Encephalos. 2015;52:14-24.

74. Sakharov Sophrony. Saint Silouan the Athonite, translated by Rosemary Edmonds Tolleshunt Knights, Essex, Monastery of St. John the Baptist, 1991.
75. Lim Vivian. The spiritual world of Isaac the Syrian. Angl Theolog Rev. 2001;83(4):908-910.

76. Brainard FS. Defining 'Mystical Experience. Journal of the American Academy of Religion. 1966;64(2):359-393.

77. Lossky V. Essai sur la theologie mystique de 1'Eglise d'Orient Le Cerf coll. Foi Vivante. 1990.

78. Baloyannis SJ. The role of economy in the philosophy of the society. Encephalos. 2014;1(3):38-46.

79. Baloyannis SJ. The existential agony. Gregory Palamas. 1987;70:30-38.

80. John Chrysostom, David G Hunter. A Comparison Between a King and a Monk/Against the Opponents of the Monastic Life. Lewiston NY: Mellen press; 1988.

81. Florovsky G. St John Chrysostom: the Prophet of Charity. St. Vladimir's Seminary Quarterly 1955;3:37-42.

82. Palmer GEH, Sherrard P, Ware K, editors. The Philokalia. The Complete Text compiled by St. Nikodimos of the Holy Mountain \& St. Makarios of Corinth, Vol. I-IV. London UK: Faber \& Faber; 1998.

83. Hierotheos V. Orthodox Psychotherapy. In: Esther ECW, editor. The Science of The Fathers. Levadia, Greece, Birth of the Theotokos Monastery, 1994.

84. Lapin A. What is "psychotherapy" in context of the Orthodox Christianity? World Cult Psychiatry Res Rev (WCPRR). 2007;2(23):80-86. 